\title{
Male participation in family planning: An untapped potential for increasing utilization of family planning services in Ondo, Southwestern Nigeria.
}

\author{
*Akande R.O. ${ }^{1}$, Adeomi A.A. ${ }^{2}$, Akande J.O. ${ }^{3}$, Israel O.K. ${ }^{1}$, Adefemi A.K. ${ }^{4}$, \\ Leramo E.O.K.
}

\begin{abstract}
Background: Men play crucial roles in the utilization of family planning services hence, ensuring their commitment to these services is essential for increasing family planning uptake. This study therefore, assessed the level of male participation in family planning services utilization and its associated factors in Ondo west LGA, Ondo State, Nigeria.
\end{abstract}

Methods: The study utilized a community-based cross-sectional design. Multi-stage sampling technique was used to select 433 eligible respondents. Quantitative data were collected using semi-structured questionnaires and analyzed using IBM SPSS version 23; bivariate and multivariate analyses were done using Chi-square and binary logistic regression respectively at $5 \%$ level of significance.

Results: $55 \%$ and $48.5 \%$ of the study participants, had poor knowledge and perception about family planning services respectively. At bivariate level, there were statistically significant associations between age $(p=0.046)$, number of children $(p<0.001)$, level of education $(p=0.023)$, and the utilization of FP services by the respondents.

Conclusion: The knowledge of the respondents about FP services was poor and if unaddressed, could infringe upon the rights of their spouses to access such services. Increasing male participation may require targeting married men for educational interventions.

Key words: Family planning, services, males, participation, utilization.

\author{
*Corresponding Author \\ Akande R.O. \\ ORCID-NO: http://orcid.org/0000-0001-8945-9624 \\ roseline.akande@bowen.edu.ng
}

\footnotetext{
${ }^{1}$ Department of Community Medicine, Bowen University, Iwo, Nigeria

${ }^{2}$ Department of Community Health, Obafemi Awolowo University, Ile-Ife, Nigeria

${ }^{3}$ Department of Chemical Pathology, Bowen University Iwo, Nigeria

${ }^{4}$ Department of Obstetrics and Gynaecology, Lagos State University, Lagos, Nigeria

${ }^{5}$ Primary Health Center, Yaba, Ondo West Local Government Area, Ondo-State, Nigeria.
} 


\title{
Participation des hommes à la planification familiale : un potentiel inexploité pour accroître l'utilisation des services de planification familiale à Ondo, dans le sud-ouest du Nigéria
}

\author{
*Akande R.O. ${ }^{1}$, Adeomi A.A. ${ }^{2}$, Akande J.O. ${ }^{3}$, Israel O.K. ${ }^{1}$, Adefemi A.K. ${ }^{4}$, \\ Leramo E.O.K.
}

\begin{abstract}
Résumé
Contexte général de l'étude : Les hommes jouent un rôle important dans l'utilisation des services de planification familiale, par conséquent, obtenir leur engagement envers ces services est essentiel pour augmenter l'adoption de la planification familiale. Par conséquent, cette étude a évalué le niveau de participation des hommes dans l'utilisation des services de planification familiale et ses facteurs associés à Ondo West, Ondo State, Nigéria.
\end{abstract}

Méthode de l'étude : Une étude transversale communautaire, les répondants étant des hommes mariés. Une technique d'échantillonnage à plusieurs degrés a été utilisée pour sélectionner 433 répondants admissibles. Les données ont été recueillies à l'aide de questionnaires semi-structurés. Les données ont été analysées à l'aide d'IBM SPSS version 23 ; des analyses bi variées et multi variées ont été effectuées en utilisant respectivement une régression logistique du chi carré et binaire à un niveau de signification de $5 \%$.

Résultat de l'étude : Environ $55 \%$ et $48,5 \%$ des participants à l'étude avaient respectivement une connaissance et une perception médiocres des services de planification familiale. Au niveau bi varié, il y avait des associations statistiquement significatives entre l'âge $(p=0,046)$, le nombre d'enfants $(p<$ $0,001)$, le niveau d'éducation ( $\mathrm{p}=0,023)$ et l'utilisation des services de PF par les répondants.

Conclusion : La connaissance des répondants sur les services de PF est faible et si elle n'est pas prise en compte, elle pourrait porter atteinte aux droits de leurs conjoints à de tels services. L'augmentation de la participation des hommes peut nécessiter de cibler les hommes mariés pour les interventions éducatives.

Mots-clés: Planification familiale, services, hommes, participation, utilisation.

\author{
*Corresponding Author \\ Akande, R.O. \\ ORCID-NO: http://orcid.org/0000-0001-8945-9624 \\ roseline.akande@bowen.edu.ng \\ ${ }^{1}$ Department of Community Medicine, Bowen University, Iwo, Nigeria \\ ${ }^{2}$ Department of Community Health, Obafemi Awolowo University, Ile-Ife, Nigeria \\ ${ }^{3}$ Department of Chemical Pathology, Bowen University Iwo, Nigeria \\ ${ }^{4}$ Department of Obstetrics and Gynaecology, Lagos State University, Lagos, Nigeria \\ ${ }^{5}$ Primary Health Center, Yaba, Ondo West Local Government Area, Ondo-State, Nigeria.
}




\section{INTRODUCTION}

Men play an integral role in family planning (FP) services including the use of modern contraception, with a consequent improvement in the health of women of reproductive age, through a reduction in maternal and child mortality (1). It has been documented that men generally can prevent the use of family planning services among women and they also represent an untapped group of potential users of FP services as well as influencers in reproductive health $(2,3)$. This is even more evident considering the multiple decision-making roles of men in reproductive health, hence they are also primarily considered as a means of increasing contraceptive prevalence (3). Globally, at least 200 million women, want to use safe and effective family planning methods, but are unable to access these services, due to a number of factors (4). The major factors hindering the utilization of family planning services as previously documented include poor knowledge about contraception, religious beliefs, financial considerations, desire for more children, fear of side effects, partner's disapproval and problems with decision-making at home amongst others $(1,5)$. In Sub-Saharan Africa, 19 million unintended pregnancies, 8 million unplanned births, 5 million abortions, 2 million miscarriages, 555,000 infant deaths and 255,000 newborn deaths reportedly occur annually as a result of unmet need for contraception $(1,4)$.

Despite the global promotion of modern contraception, uptake of family planning services has been consistently low. This suggests that some women are either deliberately not planning their pregnancies or they are experiencing problems accessing these services. Currently, Nigeria's growth rate is estimated to be between 2.5 and 3.0 percent per annum depicting a high fertility in the population and a dismal utilization of family planning services (6). The attendant consequences of low family planning services utilization include high prevalence of teenage pregnancies and maternal mortality ratio amongst others (6). Beyond limiting the reach of family planning services, gender inequality and the norms surrounding masculinity, femininity and male- female relationships have also been identified as obstacles to the healthy timing and spacing of pregnancies (7).

Traditionally, reproductive health programs have focused on women, however, most reproductive health programs are likely to be effectively utilized by women, when men are involved. This is due to the fact that involving men in family planning service uptakes, has been found to influence the partner's reproductive health decision making and consequently their behaviors (8). Previous studies have established that the role of men in the family, their relationships with their partners, availability of male-oriented educational programs, and counseling activities on family planning services , greatly influence men's knowledge and behaviour regarding family planning services (911). Willingness of husbands to participate in as well as allow their spouses to use family planning services may therefore determine the rate of achieving fertility reduction in any society (3). Recently, the role of men in family planning by population planners have received more interest as they begin to discover the importance of male influence on women's reproductive health decisions (9-12). Hence, the focus of this study on male participation in family planning services is based on assertions that most Nigerian men, have a positive attitude towards family planning, but obstacles to their participation in these services are not well understood.

This study therefore, aimed to identify the determinants of male participation in family planning services utilization in Ondo west Local Government Area (LGA), Ondo-State, Nigeria.

The objectives were to assess the knowledge, perception about modern contraceptive methods and determine the factors associated with utilization of family planning services by the married men.

\section{MATERIALS AND METHODS}

The study was carried out in Ondo State, which is one of the 36 states in Nigeria, and it is located in the South western part of the country. This was a descriptive cross-sectional study, conducted amongst married men in Ondo west LGA. There are a total number of 811 health facilities in Ondo State. Of this number, 86 health facilities are in Ondo west local government area, with majority $79,(91.9 \%)$ being Primary Health Care facilities. The local government area also have 6 private and 1 public health care facilities providing Secondary level of health care services (13).

Using the Leslie Fisher's formulae for estimating proportions in a population greater than $10,000,\left(Z^{2} \mathrm{pq} / \mathrm{d}^{2}\right)(14)$, and with an acceptable margin of error of $5 \%$, the calculated sample size was 393. After adding an anticipated non-response of $10 \%$, the sample size came to 433 respondents, who were recruited for the study using multi-stage sampling technique. 
i. Stage one: From the list of the 12 political wards in Ondo west local government area, 6 wards were selected by simple random sampling (balloting method).

ii. Stage two: From the lists of all the streets in each selected ward, 4 streets were chosen from each of the 6 wards, by simple random method using the balloting technique, making a total of 24 streets.

iii. Stage three: In all the selected streets, a mapping of the buildings were done. This was done by numbering the houses and then generating a sampling frame. Twenty houses were chosen from each selected street, making a total number of 80 houses per ward using computer aided simple random sampling (then, in each street, extra five houses were selected as replacement houses).

iv. Stage four: The final stage involved systematic random sampling. The first house was randomly selected in each selected street, and one eligible married man was interviewed from this house, and subsequently from every other Kth house. In cases where no eligible respondent was found in a selected house, such house were replaced from the replacement list.

The validity and reliability of the questionnaire were done before the final collection of data. Two experts in the field of epidemiology and medical statistics in a Nigerian university assessed the extent to which the variables in the questionnaires were relevant to the objectives of the study. Thereafter, questionnaire was pretested among married men in Idanre local government area. The responses provided helped to clarify instructions as well as modified questions or response categories where necessary.

Inclusion criteria: These include men who had been married for at least one year and gave their consent.

Data was collected using a semi-structured questionnaire, self-developed after review of relevant literatures on family planning services. Information about the knowledge of family planning methods, perception and uptake of family planning services were sought from the respondents. For knowledge assessment of the respondents, every correct response had a score of 1 and an incorrect response got 0 .
The individual knowledge score were computed and a mean knowledge score was obtained for the respondents. The respondents whose knowledge score is equal to or more than the mean score were regarded as having good knowledge while those with scores lower than the mean score were regarded as having poor knowledge. Perception of the respondents were assessed using five items on a five-point Likert scale ranging from strongly disagree (1) to strongly agree (5). The responses scored 5,4,3,2 and 1 in that order for a good perception. The sum of the scores for individual respondents were calculated, and the mean of all the scores were determined. The respondents who scored up to or above the mean were categorized as good perception.

The questionnaires were manually sorted out, entered into a computer and the obtained data were analyzed using IBM SPSS version 23. Frequency distribution tables were generated and the chi-square test was used at bivariate analysis level to compare categorical data. At multivariate level, the logistic regression was done to identify the predictors of utilization of family planning services by respondents. Significant findings were so judged at p-value less than 0.05 . Ethical clearance was obtained from the Ethical Review Committee, College of Health Sciences, Ladoke Akintola University of Technology, Osogbo and permission to carry out the study from Ondo State Ministry of Health. The respondents were informed about the nature of the study and that participation was completely voluntary. The study participants were assured of confidentiality as all questionnaires were coded without names or addresses of respondents. Signed informed consent forms were then obtained from the respondents before being recruited into the study.

\section{RESULTS}

The mean (SD) age of the respondents was $39.7 \pm 9.2$ years and $39.3 \%$ belonged to the age group 40-49 years. Majority of the study participants were married $(95.9 \%)$, and lived in monogamamous family settings $(78.3 \%)$, with most of them 311, (71.8\%) being of Yoruba ethnic descent (Table 1).

In this study, $61 \%$ of respondents had ever used any family planning methods while $39 \%$ had never used any of the available methods. Similarly, $62.8 \%$ of their spouses had ever used any family planning methods, while $37.2 \%$ had never used any of the FP methods. The commonest contraceptives that has ever been 
used by the respondents were the barrier methods; male condom $285,(65.8 \%)$ followed by withdrawal methods which accounts for $64.2 \%$ and the least ever used was sterilization 93 $(21.5 \%)$. When asked about the current FP methods used by their spouses, IUD 140, (32.3\%) and pills were reportedly the preferred contraceptives of choice and $19.6 \%$ of the men did not know the current FP method used by their wives (Table 2).

Assessment of the perception of the study participants about family planning services showed that a significant proportion (299, $69.1 \%$ ) of the men strongly disagreed that they should have family planning services discussions with their spouses. Slightly above half (222, $51.3 \%$ ) of the men also strongly disagreed about allowing their spouses to go for follow-up consultations related to family planning services. (Table 3)

The overall knowledge of the respondents in this study showed that slightly more than half of them, had poor knowledge about family planning services $238,(55 \%)$ and while a little less than half 195,(45\%) of them had good knowledge about family planning services (Figure 1).

The overall perception showed that 222, (51.3\%) of the respondents have good perception while about 211, (48.7\%) have poor perception about family planning services. (Figure 2).

At bivariate level, there were statistically significant associations between; age $(\chi 2=7.990$, $\mathrm{p}=0.046)$, number of children $(\chi 2=16.381, \mathrm{p}<$ $0.001)$, level of education $(\chi 2=8.538, p=0.023)$, and the utilization of FP services by the study participants. These relationships were such that older men, those with more children and who had tertiary level of education were more likely to utilize FP services. However, there was no statistically significant association between occupation $(p=0.683)$, occupation of spouse $(p=$ $0.737)$, marital status $(p=0.862)$, monogamous family setting $(p=0.429)$ and the utilization of FP services. (Table 4)

There was a statistically significant association between the knowledge of the respondents and their utilization of FP services $(\chi 2=17.469$ and $p<0.001)$. This relationship was such that the study participants who had good knowledge were more likely to have utilized FP services before. However, there was no statistically significant association between the perception of the respondents about family planning and their utilization of FP services $\left(\chi^{2}=\right.$ $1.207, \mathrm{p}=0.272)$. (Table 5)
When these were entered into a binary logistic regression model, knowledge $(\mathrm{p}=0.001$; $\mathrm{CI}=1.334$ to 3.066) and level of education ( $\mathrm{p}=$ 0.048 ; $\mathrm{CI}=1.890$ to 5.905 ) remained the only statistically significant explanatory variables for utilization of family planning services among the respondents. Respondents who had good knowledge were twice more likely to utilize family planning services $(\mathrm{OR}=2.022)$. Also, respondents who had tertiary level of education were 3 times more likely to utilize family planning services compared to those with primary and secondary levels of education $(\mathrm{OR}=3.312 ; 95 \%$ CI: $2.760-5.935)($ Table 6$)$.

\section{DISCUSSION}

Modern contraception is an integral component of reproductive health and has positive effects on the health of women. The use of any family planning method, depends on the person's knowledge about the different family planning methods available and the willingness of both spouses to utilize the family planning services $(1,15)$. In this study, more than half of the study participants, had poor knowledge about family planning services. Knowledge level of men on FP services amongst respondents in the current study is lower than that reported in previous studies done in the northern part of Nigeria (63.5\%) and in Ethiopia $(58.4 \%)(16,17)$. This may be connected to the fact that most family planning activities in the recent past, focused majorly on women (18). However, the number of reproductive health interventions in Nigeria has risen with increased exposure to health education and media advocacy in recent times (19). Odu et al in their study reported that Nigerian men just like their counterparts in many West African countries have high awareness about modern family planning methods but lacked adequate information to motivate and guide themselves and their spouses towards its adoption as a way of life (20). Consequently, the impact of men's involvement in family planning and the use of modern contraceptive methods is directly linked to men's knowledge. Therefore, men's utilization of family planning services requires knowledge about appropriate contraceptive methods and sharing concerns about their partners' family planning practices.

The commonest contraceptives that were ever used by our respondents were the male condom, followed by withdrawal methods and the least ever used was sterilization. Consistent findings were reported by previous studies conducted among men in South western, Nigeria, 
Ghana and Malawi $(10,11,18,21)$. Similarly, Akafuah et al and Shattuck et al in their own studies found that about $50 \%$ and $56 \%$ of their participants respectively mentioned the condom as the most common and popular modern family planning device that they know and had ever used.(15,22). Men's level of perception about discussions centered on family planning services with their spouses was poor in this study with only half of them encouraging their wives to go for follow-up FP services. This finding suggests poor spousal communications about family planning choices as well as services utilization at the family level could make it difficult for couples to discuss and access family planning. However, discussion between spouses have been documented to increase utilization of family planning services with evidences from Ethiopia, Ghana, Malawi, Pakistan and Nigeria $(3,5,9,15,23,24)$. Furthermore, about two thirds of the married women in a survey conducted in Uganda reported that family planning decisionmaking was either undertaken jointly or exclusively by male partners and in other instances issues related to children and child birth are ceded as the sole responsibility of the women $(12,25)$. Encouraging more male participation in contraceptive communication and decisionmaking processes, may lead to increased use of family planning services and ultimately achievement of couples' reproductive goals (26).

In this study, the first determinant associated with male participation and utilization of FP services was the age of the respondents. More than two-thirds of the men belonging to the 30-39 years age group and 40-49 years had ever used family planning services. This may suggest that male participation in family planning and reproductive health increases as their age increases. These findings agree with those of a study done in Bangladesh on male involvement in family planning services (27). Their study results revealed that about $82.8 \%$ of the men who participate in family planning services were within the age group 40-49 years. This further agreed with the fact that the association between age of the husband and male participation in family planning is strongly significant. The number of children was another factor identified as a determinant of male participation and utilization of FP services in this study. In the current study, men who had three or more children were found to be involved in family planning services than those who had no child. Previous studies corroborates this finding, that men having more children not only enhances male participation but also provide appropriate support to their partner's family planning choices and subsequent utilization of FP services $(17,27)$. Consequent enormous financial burden and responsibilities placed on men with large families may be a reason for this.

The fact that level of education was positively associated with utilization of FP services is also worth noting. This is concurrent with results from previous studies which demonstrated that husbands with higher education showed the highest percentage of approval for family planning services $(9,24)$. The key predictors of male participation and utilization of family planning services in this study was level of education and the knowledge about FP services. Men who had good knowledge about family planning services were 2 times more likely to have utilized family planning services compared to those with poor knowledge (OR=2.02; 95\% CI: 1.334-3.066). Likewise, respondents who had tertiary level of education were 3 times more likely to utilize family planning services compared to those with primary and secondary levels of education $(\mathrm{OR}=3.312 ; 95 \%$ CI: $2.760-5.935)$. A plausible reason for this, may be due to the fact that men's utilization requires knowledge about appropriate family planning services, reinforcing the importance of men's education. A study carried out among married men in Ondo and Imo State also revealed that men with post-secondary education were five times as likely as men without any formal education to have utilized modern family planning services (19).

Study Limitation: The limitation of the present study is its cross-sectional nature, making it impossible to determine causation. Secondly, social desirability bias could be introduced because of the use of the intervieweradministered type of data collection tool.

\section{CONCLUSION}

The knowledge of the respondents about FP services is still poor. Unaddressed poor knowledge of men about FP services could affect FP services utilization and also infringe upon the rights of their spouses to such services, by virtue of their role as primary decision-makers in the family. Increasing male participation may require targeting married men for educational interventions within the community, as this will significantly improve their knowledge as well as utilization of family planning services. 
Conflicts of Interest: The authors declare that there is no conflict of interest.

Acknowledgement: We are indeed grateful to the Chairman of Ondo West Local Government Area for his immense contributions towards the completion of this study. We also appreciate the Councilors of the wards used for data collection, for their kind support in allowing us to conduct this study.

\section{REFERENCES}

1. Afriyie P, Tarkang EE. Factors influencing use of modern contraception among married women in Ho west district, Ghana: Descriptive crosssectional study. Pan Afr Med J. 2019;33:1-11.

2. Soremekun O. Factors that Influence Male Involvement in Family planning: A Qualitative study of men of reproductive age in Ibadan North East and North-West: Eur J Public Health. $2014 ; 24(2): 2014$. Available at: https://academic.oup.com/eurpub/article/24/sup pl 2/cku151-079/2838879

3. Berhane A, Biadgilign S, Amberbir A, Morankar S, Berhane A, Deribe K. Men's knowledge and spousal communication about modern family planning methods in Ethiopia. Afr J Reprod Health. 2011;15(4):24-32. Available at: https://www.ajol.info/index.php/ajrh/article/vie w/74786

4. Ogboghodo E, Adam V, Wagbatsoma V. Prevalence and determinants of contraceptive use among women of child-bearing age in a rural community in southern Nigeria. J Community Med Prim Heal Care. 2017;29(2):97-107-107. A v a i 1 a b l e a t : https://www.ajol.info/index.php/jemphc/article/ view/162455

5. Kassa M, Abajobir AA, Gedefaw M. Level of male involvement and associated factors in family planning services utilization among married men in Debremarkos town, Northwest Ethiopia. BMC Int Heal Hum Rights. $2014 ; 14(33): 1-8$. Available at : https://link.springer.com/article/10.1186/s12914 $-014-0033-8$

6. Ekpenyong M, Nzute A, Odejimi O, Abdullahi A. Factors influencing utilisation of family planning services among female of reproductive age (1545 years) in Bauchi local government area, Bauchi state. Nurs Palliat Care. 2018;3(2):1-6. Available at: https://www.oatext.com/factorsinfluencing-utilisation-of-family-planningservices-among-female-of-reproductive-age15-45-years-in-bauchi-local-government-areabauchi-state.php\#gsc.tab $=0$

7. Schuler SR, Rottach E, Mukiri P. Gender norms and family planning decision-making in Tanzania: A qualitative study. J Public Health Africa. 2011;2(2):102-7. Available at: https://www.ncbi.nlm.nih.gov/pmc/articles/PM

\section{C5345498/}

8. Mustafa G, Azmat SK, Hameed W, Ali S, Ishaque M, Hussain W, et al. Family Planning Knowledge, Attitude and Practices Among Married Men and Women in Rural Areas of Pakistan. Internatoinal J Reprod Med. 2015;2015(190520):8. Available at: https://www.hindawi.com/journals/ijrmed/2015 /190520/

9. Hussain H, Wahid MI, Khan AA, Rehman ZU, Iftikhar B, Ismail $\mathrm{T}$. The Role of Effective Communication Between Couples about Contraceptive Use. J Med Sci. 2012;20(1):19-21.

10. Ijadunola MY, Abiona TC, Ijadunola KT, Afolabi OT, Esimai OA, OlaOlorun FM. Male involvement in family planning decision making in Ile-Ife, Osun State, Nigeria. Afr J Reprod Health. 2010;14(4 Spec no.):43-50. Available at: https://www.ajol.info/index.php/ajrh/article/vie $\mathrm{w} / 67833$

11. Vouking MZ, Evina CD, Tadenfok CN. Male involvement in family planning decision making in sub-Saharan Africa- what the evidence suggests. Pan Afr Med J 2014;19:1-5. Available

https://www.ncbi.nlm.nih.gov/pmc/articles/PM C4406389/

12. Dougherty A, Kayongo A, Deans S, Mundaka J, Nassali F, Sewanyana J, et al. Knowledge and use of family planning among men in rural Uganda. BMC Public Health. 2018;18(1):1-6. Available

https://www.researchgate.net/publication/32920 1210_Knowledge_and_use_of family_plannin g_among men in rural_Uganda/link/5fc2294b $4 \overline{5} 8515 \mathrm{~b} 7977 \mathrm{c} \overline{\mathrm{d}} 3 \overline{1} \overline{7} /$ download

13. Directory of Medical and Health Institution. List of Coded Health Facilities in Ondo-State. 2015.

14. Olawuyi JF (ed. Biostatistics: A foundation course in health sciences: formulas for calculating sample size. 1st ed. Toyin Alabi Printing Co; 1996. 114-115 p.

15. Akafuah RA, Sossou MA. Attitudes toward and use of knowledge about family planning among Ghanaian men. Int J Mens Health. 2008;7(2):109-20.

16. Duze, Mustaphapha. C Mohammed IZ. Male Knowledge, Attitudes and Family Planning Practices in Northern Nigeria. Afr J Reprod Health. 2006;10(3):54-65. Available at: https://www.ajol.info/index.php/ajrh/article/vie $\mathrm{w} / 7899$

17. Wondim G, Degu G, Teka Y, Diress G. Male Involvement in Family Planning Utilization and Associated Factors in Womberma District, Northern Ethiopia? Community-Based CrossSectional Study. Open Access J Contracept. $2020 ; 11: 197-207$. Available at: https://www.ncbi.nlm.nih.gov/pmc/articles/PM C7781357

18. Manortey S, Missah K. Determinants of Male 
Involvement in Family Planning Services: A Case Study in the Tema Metropolis, Ghana. OALib. 2020;07(01):1-21. Available at: https://www.scirp.org/html/97969_97969.htm

19. Oyediran KA, Ishola GP, Feyisetan BJ. Factors affecting ever-married men's contraceptive knowledge and use in Nigeria. J Biosoc Sci. 2002;34(4):497-510

20. Odu OO, Ijadunola KT, Komolafe JO, Adebimpe WT. Men's knowledge of and attitude with respect to family planning in a suburban Nigerian community. Niger J Med. 2006;15(3):260-5.

21. Dral AA, Tolani MR, Smet E, Van Luijn A. Factors influencing male involvement in family planning in Ntchisi district, Malawi - A qualitative study. Afr J Reprod Health [Internet]. $2018 ; 22(4): 35-43$. Available at: https://www.ajrh.info/index.php/ajrh/article/vie $\mathrm{w} / 1610$

22. Shattuck D, Kerner B, Gilles K, Hartmann M, Ng'ombe T, Guest G. Encouraging contraceptive uptake by motivating men to communicate about family planning: The Malawi Male Motivator project. Am J Public Health [Internet]. 2011;101(6):1089-95. Available at: https://ajph.aphapublications.org/doi/full/10.21 05/AJPH.2010.300091

23. Hardee K, Croce-Galis M, Gay J. Are men well served by family planning programs? Reprod Health [Internet]. 2017;14(1):1-12. Available at: http://dx.doi.org/10.1186/s12978-017-0278-5

24. Nmadu AG, Joshua IA, Omole VN, Usman NO, Igboanusi J-CC, Gobir AA. Male involvement in family planning in Northern Nigeria: A review of literature. J Med Trop. 2019;19:116-22. A $v$ a i 1 a b 1 e a $\mathrm{t}$ : https://www.jmedtropics.org/downloadpdf.asp? $\mathrm{i} \quad \mathrm{s} \quad \mathrm{s} \quad \mathrm{n}=\begin{array}{llll}2 & 2 & 7 & 6\end{array}$ 7096; year $=2019$; volume $=21 ;$ issue $=1 ;$ spage $=6 ; \mathrm{e}$ page $=9$; aulast $=$ Nmadu;type $=2$

25. Namasivayam A, Lovell S, Namutamba S, Schluter PJ. Predictors of modern contraceptive use among women and men in Uganda: A population-level analysis. BMJ Open. $2020 ; 10(2): 1-11$. Available at https://bmjopen.bmj.com/content/10/2/e034675

26. Koffi TB, Weidert K, Bitasse EO, Mensah MAE, Emina J, Mensah S, et al. Engaging men in family planning: Perspectives from married men in Lomé, Togo. Glob Heal Sci Pract. 2018;6(2):316-27.

27. Kamal MM, Islam MS, Alam MS, Hassan E. Determinants of Male Involvement in Family Planning and Reproductive Health in Bangladesh. Am J Hum Ecol. 2013;2(2):83-93. A v a i 1 a b 1 e a t : http://worldscholars.org/index.php/ajhe/article/ view/0202 6

How to cite this article:

Akande RO., Adeomi A.A., Akande J.O., Israel O.K., Adefemi A.K., Leramo E.O.K. Male Participation in family planning: An untapped potential for increasing utilization of Family planning Services in Ondo, Southwestern Nigeria. Research Journal of Health Sciences, 2021, 9(4): 330-343 
Table 1: Socio-demographic characteristics of the Respondents $(N=433)$

\begin{tabular}{|c|c|c|}
\hline Socio-demographic variables & Frequency & Percentage (\%) \\
\hline \multicolumn{3}{|l|}{ Age (in years) } \\
\hline$<30$ & 54 & 12.5 \\
\hline $30-39$ & 142 & 32.8 \\
\hline $40-49$ & 170 & 39.3 \\
\hline$=50$ & 67 & 15.5 \\
\hline \multicolumn{3}{|l|}{ Mean age $(\mathrm{SD})=39.7( \pm 9.2)$} \\
\hline \multicolumn{3}{|l|}{ Ethnicity } \\
\hline Yoruba & 311 & 71.8 \\
\hline Igbo & 37 & 8.5 \\
\hline Hausa & 30 & 6.9 \\
\hline Others & 55 & 12.7 \\
\hline \multicolumn{3}{|l|}{ Level of education } \\
\hline No formal education & 43 & 9.9 \\
\hline Primary & 30 & 6.9 \\
\hline Secondary & 54 & 12.5 \\
\hline Higher institution & 293 & 67.7 \\
\hline Post graduate education & 13 & 3.0 \\
\hline \multicolumn{3}{|l|}{ Occupation } \\
\hline Unemployed & 62 & 14.3 \\
\hline Skilled worker (eg professionals and entrepreneurs) & 87 & 20.1 \\
\hline Semi-skilled (eg Artisans) & 245 & 56.6 \\
\hline Unskilled (eg Manual workers, cleaners) & 39 & 9.0 \\
\hline \multicolumn{3}{|l|}{ Occupation of spouse } \\
\hline Unemployed & 68 & 15.7 \\
\hline Skilled worker (eg professionals and entrepreneurs) & 99 & 22.9 \\
\hline Semi-skilled (eg Artisans) & 219 & 50.6 \\
\hline Unskilled (eg Manual workers, cleaners) & 47 & 10.9 \\
\hline \multicolumn{3}{|l|}{ Marital status } \\
\hline Married & 415 & 95.9 \\
\hline Widowed & 8 & 1.8 \\
\hline Separated & 10 & 2.3 \\
\hline \multicolumn{3}{|l|}{ Family setting } \\
\hline Monogamous & 339 & 78.3 \\
\hline Polygamous & 94 & 21.7 \\
\hline
\end{tabular}


Table 2: Utilization of Family Planning Services by Respondents $(n=433)$

\begin{tabular}{|c|c|c|}
\hline Variables & Frequency & Percentage \\
\hline \multicolumn{3}{|c|}{ Ever used family planning methods } \\
\hline Yes & 264 & 61.0 \\
\hline No & 169 & 39.0 \\
\hline \multicolumn{3}{|l|}{ Method ever used* } \\
\hline Male condom & 285 & 65.8 \\
\hline Withdrawal method & 278 & 64.2 \\
\hline Standard day method & 139 & 32.1 \\
\hline Male sterilization & 93 & 21.5 \\
\hline \multicolumn{3}{|l|}{ Current method being used* } \\
\hline Male condom & 226 & 52.2 \\
\hline Withdrawal method & 187 & 43.2 \\
\hline Standard day method & 91 & 21.0 \\
\hline Male sterilization & 61 & 14.1 \\
\hline \multicolumn{3}{|c|}{ Ever use of any family planning method by spouse } \\
\hline Yes & 272 & 62.8 \\
\hline No & 161 & 37.2 \\
\hline \multicolumn{3}{|c|}{ Method spouse is currently using* } \\
\hline Pills & 130 & 30.0 \\
\hline Intra- uterine device (IUD) & 140 & 32.3 \\
\hline Female condom & 102 & 23.6 \\
\hline Implants (Implanol \& Jadellle) & 68 & 15.7 \\
\hline Withdrawal Methods & 67 & 15.5 \\
\hline Bilateral tubal ligation & 36 & 8.3 \\
\hline Lactation amenorrrhea & 35 & 8.1 \\
\hline Don’t know & 85 & 19.6 \\
\hline \multicolumn{3}{|c|}{ Where spouse accesses family planning services } \\
\hline Health facilities & 290 & 67.0 \\
\hline Pharmacy & 150 & 34.6 \\
\hline Drug vendor & 69 & 15.9 \\
\hline Traditional birth attendants & 38 & 8.8 \\
\hline
\end{tabular}

*Multiple responses allowed 
Table 3: Perception of Respondents about Family Planning Services $(n=433)$

\begin{tabular}{llllll}
\hline & \multicolumn{2}{l}{ Perception (\%) } & & & \\
\cline { 2 - 6 } & $\begin{array}{l}\text { Strongly } \\
\text { agree }\end{array}$ & Agree & Indifferent & Disagree & $\begin{array}{c}\text { Strongly } \\
\text { disagree }\end{array}$ \\
\hline $\begin{array}{l}\text { FP should be discussed with } \\
\text { spouse }\end{array}$ & $8(1.8)$ & $13(3.0)$ & $17(3.9)$ & $96(22.2)$ & $299(69.1)$ \\
$\begin{array}{l}\text { I support my spouse by } \\
\text { encouraging her to go for FP } \\
\text { follow-up }\end{array}$ & $13(3.0)$ & $18(4.2)$ & $34(7.9)$ & $146(33.7)$ & $222(51.3)$ \\
$\begin{array}{l}\text { I support my spouse by } \\
\text { showing understanding }\end{array}$ & $13(3.0)$ & $16(3.7)$ & $35(8.1)$ & $143(33.0)$ & $226(52.2)$ \\
when she has FP side effects & & & & & \\
$\begin{array}{l}\text { Only women should use FP } \\
\begin{array}{l}\text { My spouse has the right to } \\
\text { choose any FP she desires }\end{array}\end{array}$ & $25(5.8)$ & $64(14.8)$ & $38(8.8)$ & $149(34.4)$ & $157(36.3)$ \\
$\begin{array}{l}\text { Use of FP could reduce } \\
\text { men's ego and authority }\end{array}$ & $87(20.1)$ & $94(21.7)$ & $47(10.9)$ & $120(27.7)$ & $85(19.6)$ \\
$\begin{array}{l}\text { Use of FP by men could } \\
\text { reduce fertility }\end{array}$ & $75(17.3)$ & $90(20.8)$ & $54(12.5)$ & $114(26.3)$ & $100(23.1)$ \\
$\begin{array}{l}\text { My religion is against FP } \\
\text { FP encourages promiscuity }\end{array}$ & $81(18.7)$ & $99(22.9)$ & $67(15.5)$ & $97(22.4)$ & $89(20.6)$ \\
\hline
\end{tabular}


Table 4: Socio-demographic factors associated with the Utilization of FP by Respondents $(n=433)$

\begin{tabular}{|c|c|c|c|}
\hline \multirow[t]{2}{*}{ Variables } & \multicolumn{2}{|c|}{ Ever used FP services } & \multirow[t]{2}{*}{ Statistics } \\
\hline & Yes $(\%)$ & No $(\%)$ & \\
\hline \multicolumn{4}{|l|}{ Age (in years) } \\
\hline$<30$ & $24(44.4)$ & $30(55.6)$ & \multirow{4}{*}{$\begin{array}{l}\chi^{2}=7.990 \\
d f=3 \\
p=0.046^{*}\end{array}$} \\
\hline $30-39$ & $92(64.8)$ & $50(35.2)$ & \\
\hline $40-49$ & $109(64.1)$ & $61(35.9)$ & \\
\hline$=50$ & $39(58.2)$ & $28(41.8)$ & \\
\hline \multicolumn{4}{|l|}{ Level of education } \\
\hline No formal education & $33(76.7)$ & $10(23.3)$ & \multirow{4}{*}{$\begin{array}{l}\chi^{2}=8.538 \\
\mathrm{df}=3 \\
* \mathrm{p}=0.023\end{array}$} \\
\hline Primary & $24(63.3)$ & $19(36.7)$ & \\
\hline Secondary & $29(53.7)$ & $25(46.3)$ & \\
\hline Higher institution & $178(60.8)$ & $115(39.2)$ & \\
\hline \multicolumn{4}{|l|}{ Occupation } \\
\hline Unemployed & $42(67.7)$ & $20(32.3)$ & \multirow{4}{*}{$\begin{array}{l}\chi^{2}=1.499 \\
d f=3 \\
p=0.683\end{array}$} \\
\hline Skilled worker (eg professionals) & $51(58.6)$ & $36(41.4)$ & \\
\hline Semi-skilled (eg Artisans) & $147(60.0)$ & $98(40.0)$ & \\
\hline Unskilled (eg Manual workers) & $24(61.5)$ & $15(38.5)$ & \\
\hline \multicolumn{4}{|l|}{ Occupation of spouse } \\
\hline Unemployed & $41(60.3)$ & $27(39.7)$ & \multirow{4}{*}{$\begin{array}{l}\chi^{2}=1.269 \\
d f=3 \\
p=0.737\end{array}$} \\
\hline Skilled worker (eg professionals) & $61(61.6)$ & $38(38.4)$ & \\
\hline Semi-skilled (eg Artisans) & $130(59.4)$ & $89(40.6)$ & \\
\hline Unskilled (eg Manual workers) & $32(68.1)$ & $15(31.9)$ & \\
\hline \multicolumn{4}{|l|}{ Marital status } \\
\hline Married & $252(60.7)$ & $163(39.3)$ & \multirow{3}{*}{$\begin{array}{l}\mathrm{LR}=0.748 \\
\mathrm{df}=2 \\
\mathrm{p}=0.052\end{array}$} \\
\hline Widowed & $5(62.5)$ & $3(37.5)$ & \\
\hline Separated & $7(70.0)$ & $3(30.0)$ & \\
\hline \multicolumn{3}{|l|}{ Family setting } & \multirow{3}{*}{$\begin{array}{l}\chi^{2}=0.629 \\
d f=1 \\
p=0.429\end{array}$} \\
\hline Monogamous & $210(61.9)$ & $129(38.1)$ & \\
\hline Polygamous & $54(57.4)$ & $40(42.6)$ & \\
\hline \multicolumn{4}{|l|}{ Number of children } \\
\hline None & $12(57.1)$ & $9(42.9)$ & \multirow{4}{*}{$\begin{array}{l}\chi^{2}=16.381 \\
d f=3 \\
p<0.001 *\end{array}$} \\
\hline $1-2$ & $89(54.6)$ & $74(45.4)$ & \\
\hline $3-4$ & $136(71.2)$ & $55(28.8)$ & \\
\hline$>4$ & $27(46.6)$ & $31(53.4)$ & \\
\hline
\end{tabular}

* Statistically significant LR - likelihood ratio used

Table 5: Association between Knowledge, Perception and Utilization of FP Services by Respondents $(n=433)$

\begin{tabular}{llll}
\hline Variables & \multicolumn{2}{c}{ Ever used FP } & \multirow{2}{*}{ Statistics } \\
\cline { 2 - 3 } & \multicolumn{1}{l}{ Yes (\%) } & No (\%) & \\
\hline Knowledge about FP & & & $\chi^{2}=17.469$ \\
Poor & $124(52.1)$ & $114(47.9)$ & $\mathrm{df}=1$ \\
Good & $140(71.8)$ & $55(28.2)$ & $\mathrm{p}<0.001^{*}$ \\
& & & \\
Perception about FP & & & $\chi^{2}=1.207$ \\
Poor & $133(63.6)$ & $76(36.4)$ & $\mathrm{df}=1$ \\
Good & $131(58.5)$ & $93(41.5)$ & $\mathrm{p}=0.272$ \\
\hline * Statistically significant & & &
\end{tabular}

* Statistically significant 
Table 6: Predictors of Utilization of Family Planning Services by Respondents

\begin{tabular}{|c|c|c|c|c|}
\hline \multirow[t]{2}{*}{ Variables } & \multirow[t]{2}{*}{ p-value } & \multirow{2}{*}{$\begin{array}{l}\text { Odds } \\
\text { ratio }\end{array}$} & \multicolumn{2}{|c|}{ Confidence interval } \\
\hline & & & Lower & Upper \\
\hline \multicolumn{5}{|l|}{ Age (in years) } \\
\hline$<30$ & 0.242 & 1.574 & 0.736 & 3.365 \\
\hline $30-39$ & 0.405 & 0.769 & 0.414 & 1.428 \\
\hline $40-49$ & 0.445 & 0.790 & 0.432 & 1.445 \\
\hline \multicolumn{5}{|c|}{$=50$ (reference value $)$} \\
\hline \multicolumn{5}{|c|}{ Number of children } \\
\hline \multicolumn{5}{|c|}{ None (reference value) } \\
\hline $1-2$ & 0.767 & 1.154 & 0.446 & 2.983 \\
\hline $3-4$ & 0.358 & 0.640 & 0.247 & 1.657 \\
\hline$>4$ & 0.308 & 1.719 & 0.607 & 4.870 \\
\hline \multicolumn{5}{|l|}{ Level of education } \\
\hline \multicolumn{5}{|c|}{ No formal education(reference value) } \\
\hline Primary & 0.089 & 1.725 & 0.16 & 1.394 \\
\hline Secondary & 0.360 & 0.754 & 0.591 & 1.273 \\
\hline Higher institution & $0.048^{*}$ & 3.312 & 2.760 & 5.935 \\
\hline \multicolumn{5}{|c|}{ Knowledge about FP } \\
\hline \multicolumn{5}{|c|}{ Poor (reference value) } \\
\hline Good & $0.001 *$ & 2.022 & 1.334 & 3.066 \\
\hline
\end{tabular}

* Statistically significant

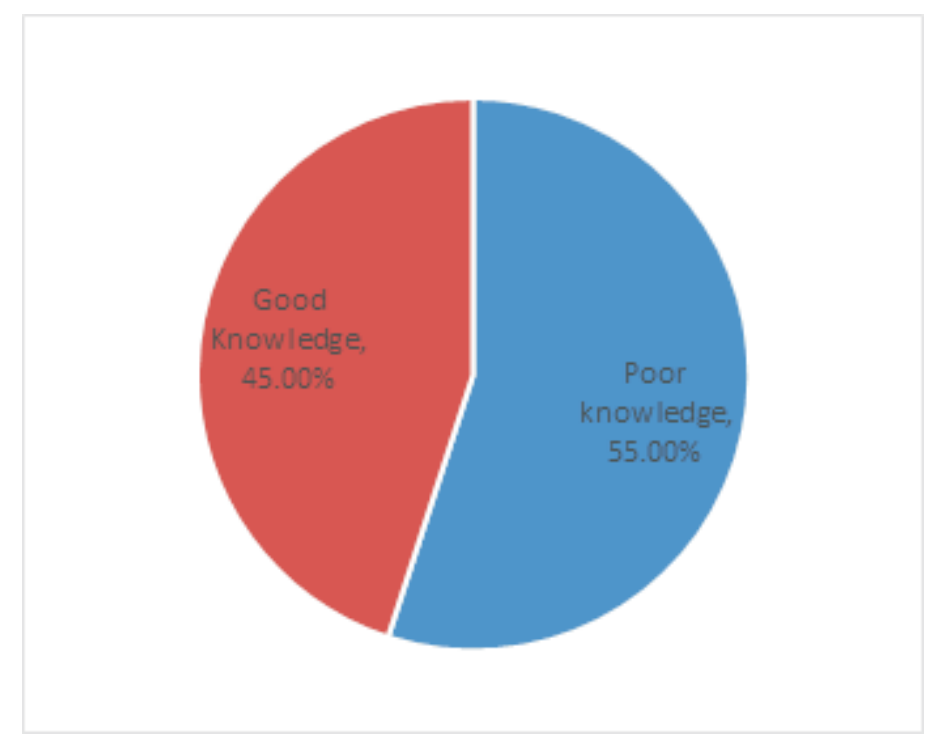

Figure 1: Overall knowledge about Family Planning services among the Respondents $(\mathrm{N}=433)$ 


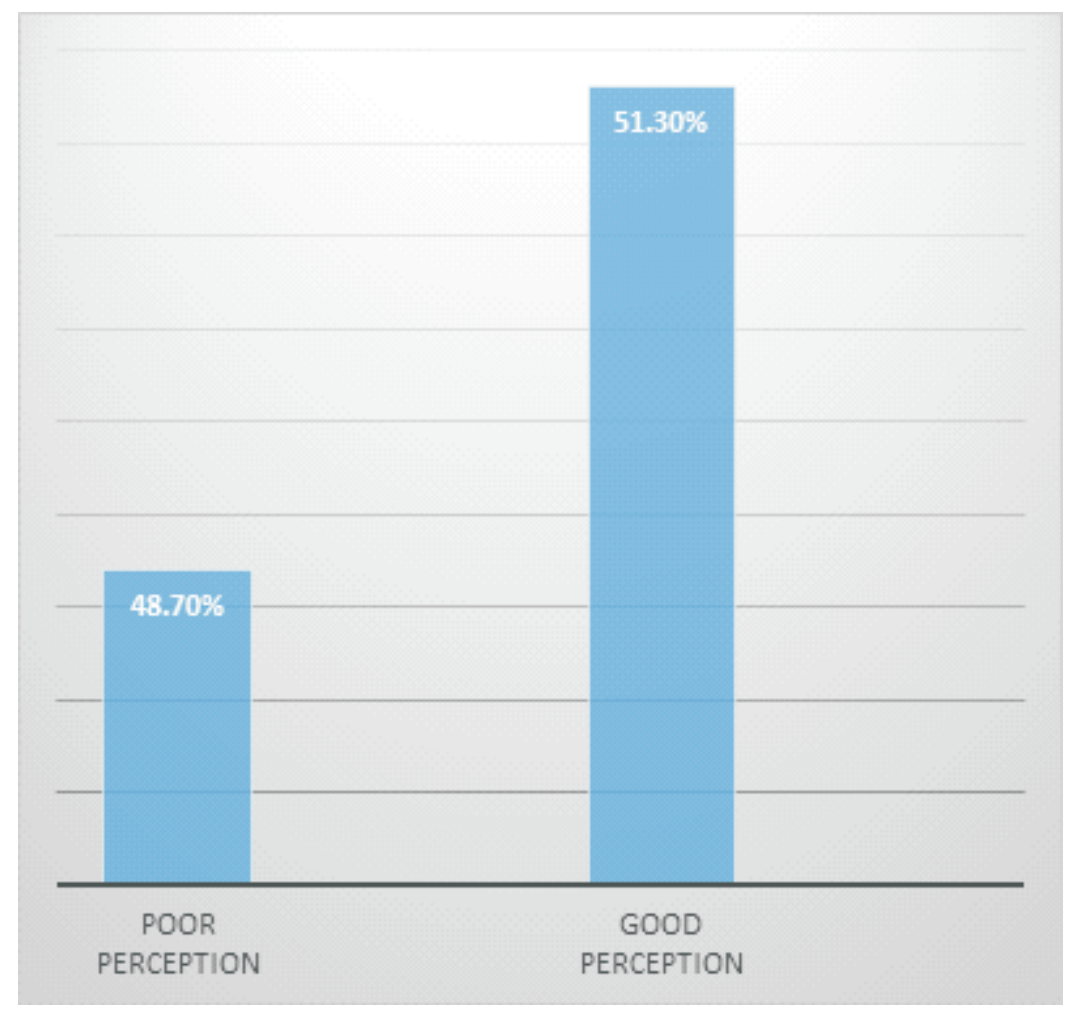

Figure 2: Overall perception of the respondents about family planning services $(N=433)$ 